\title{
Half-sandwich ruthenium, rhodium and iridium complexes of triazolopyridine ligand: Synthesis and structural studies
}

\author{
NARASINGA RAO PALEPU and MOHAN RAO KOLLIPARA* \\ Centre for Advanced Studies in Chemistry, North-Eastern Hill University, Shillong, Meghalaya 793 022, India \\ Email:mohanrao59@gmail.com
}

MS received 5 October 2016; revised 23 November 2016; accepted 29 November 2016

\begin{abstract}
Triazolopyridine ligand, \{3-(2-pyridyl)-[1,2,3]triazolo[1,5-a]-pyridine\}, $\mathbf{L}$ was synthesized by reaction of $p$-toulenesulphonyl hydrazine and dipyridyl ketone in the presence of acetic acid. Half-sandwich ruthenium, rhodium and iridium complexes [1-4] have been synthesized by reaction of $\left[\left\{(\text { arene }) \mathrm{MCl}_{2}\right\}_{2}\right]$ (arene $=p$-cymene/benzene/Cp* and $\mathrm{M}=\mathrm{Ru} / \mathrm{Rh} / \mathrm{Ir}$ ) with ligand $\mathbf{L}$ in methanol. The reaction in 1:2 (M:L) ratio has yielded all mononuclear cationic complexes such as $\left[(\right.$ arene $\left.) \mathrm{ML} \kappa_{\mathrm{N} \cap \mathrm{N}}^{2} \mathrm{Cl}\right] \mathrm{PF}_{6}$, where $\{($ arene $) \mathrm{M}\}=(p$-cym $) \mathrm{Ru}$ (1), (benz) Ru (2), $\mathrm{Cp} * \mathrm{Rh}(3)$ and $\mathrm{Cp} * \operatorname{Ir}(4)$. All the complexes were characterized by spectral studies and the solid state structures of complexes, $\mathbf{1}$ and $\mathbf{3}$ were unambiguously determined by crystallographic studies.
\end{abstract}

Keywords. triazolylpyridine; ruthenium; rhodium; iridium.

\section{Introduction}

Platinum group metals containing heterocyclic nitrogen based ligands exhibit significant photochemical properties, catalytic activities, electrochemical behaviour as well as cytotoxic activities. ${ }^{1-9}$ Triazolopyridine structures are fundamental building blocks for numerous pharmaceutical and functional materials. ${ }^{10}$ In general, the ligand under study i.e., [1,2,3]triazolo[1,5-a] pyridines have been synthesized by the oxidative cyclization of 2-pyridyl ketone hydrazones by using oxidants such as $\mathrm{Pb}(\mathrm{OAc})_{2}$, copper salts, $\mathrm{MnO}_{2}$, hypervalent iodine, $\mathrm{Ag}_{2} \mathrm{O}$, Ni peroxide, etc. ${ }^{11-15}$ Synthesis of this ligand is also possible by the reaction of 2-pyridyl ketone with tosylhydrazine in $\mathrm{NaOH} .{ }^{16}$ In our attempt to prepare a Schiff base by condensing tosylhydrazine with dipyridyl ketone using glacial acetic acid, we ended up with the triazolylpyridine. Curiously, this ring system has been ignored as a ligand in coordination chemistry. There have been only a few reports of complexes with a [1,2,3]triazolo[1,5-a] pyridine unit acting as a donor to a metal centre. ${ }^{17-21}$ Ruthenium complexes of the ligand under study were synthesized containing 2,2'-bipyridine (bipy) auxiliary ligands and their electrochemistry were delineated. ${ }^{22}$ Hitherto, we have synthesized numerous arene metal complexes of various nitrogen donor ligands and explored their structures and various bonding modes. ${ }^{23,24}$

\footnotetext{
*For correspondence
}

According to our knowledge, there are no reports of complexes of arene metal complexes with the ligand under study. We have synthesized and characterized the ruthenium, rhodium and iridium arene complexes with this ligand $[1,2,3]$ triazolo[1,5-a] pyridine $(\mathbf{L})$.

\section{Experimental}

\subsection{Materials and methods}

All the reactions were carried out without using any inert atmosphere. Metal halides $\mathrm{MCl}_{3}\left(\mathrm{H}_{2} \mathrm{O}\right)_{\mathrm{n}}(\mathrm{M}=\mathrm{Ru}, \mathrm{Rh}$ and $\mathrm{Ir})$ were purchased from Arora Matthey Limited. Pentamethylcyclopentadiene (Sigma-Aldrich), $\alpha$-Phellandrene (Merck), $p$-toluene sulphonyl hydrazine (Sigma-Aldrich), dipyridyl ketone (Sigma-Aldrich), silica gel (Hi-Media) were used as received. All the solvents used for syntheses were dried and distilled prior to use according to the standard procedures and stored over activated molecular sieves. ${ }^{25}$ Dichloromethane, chloroform and hexane were dried over calcium chloride and methanol was dried using calcium oxide. Precursor compounds of ruthenium, rhodium and iridium were prepared according to the literature methods. ${ }^{26,27}$ Infrared (IR) spectra were recorded on a Perkin-Elmer 983 spectrophotometer with the compounds dispersed in $\mathrm{KBr}$ discs. ${ }^{1} \mathrm{H}$ NMR spectra were recorded with Bruker Avance II $400 \mathrm{MHz}$ spectrometer. Chemical shifts for ${ }^{1} \mathrm{H}$ NMR are reported using tetramethylsilane (TMS) as the internal standard and were recorded in deuterated dimethyl sulphoxide (DMSO- $\mathrm{d}_{6}$ ). UV-Vis spectra were recorded by using Perkin-Elmer lambda 25 spectrophotometer. Mass spectra were recorded on Q-T of APCI-MS HAB 273 instrument. 
Single crystals selected from the samples were analyzed on Oxford Diffraction Xcalibur Eos Gemini diffractometer using Mo-K $\alpha$ radiation $(\lambda=0.71073 \AA)$ in the whole reciprocal sphere. Data reduction and processing were carried out by CrysAlisPro (Agilent Technologies Ltd., Oxfordshire, UK) suite of programs. ${ }^{28}$ All the structures were solved by direct methods with SHELXS-9. ${ }^{29}$ (Göttingen, Germany) and the molecular model refined by the full-matrix least squares procedure on $\mathrm{F}^{2}$ with SHELXL-97. ${ }^{30}$ All the nonhydrogen atoms were refined anisotropically while hydrogen atoms were placed in geometrically idealized positions and constrained to ride on their parent atoms. The molecular structures presented as ORTEP diagrams for all the complexes were drawn with ORTEP-3 software. ${ }^{31}$ The packing diagrams for the molecular structures of all the complexes were drawn using Mercury 3.6 software. $^{32}$

\subsection{Synthesis of ligand}

A mixture of $p$-toulenesulphonyl hydrazine (200 mg, $1.29 \mathrm{mmol})$ and dipyridyl ketone $(238 \mathrm{mg}, 1.29 \mathrm{mmol})$ along with two drops of glacial acetic acid was refluxed in methanol for $6 \mathrm{~h}$ (Scheme 1). The solvent was removed using rotavapor and the product, yellow oily mixture was passed through silica gel column using hexane and methanol $(1: 1)$ as solvents. The compound was obtained as yellow solid. M.p.: $160^{\circ} \mathrm{C}$. Yield: $(75 \%)$. FTIR (KBr pellet, $\left.\mathrm{cm}^{-1}\right): 3079$ $v_{(\mathrm{C}-\mathrm{H})}, 1631 v_{(\mathrm{C}=\mathrm{N})}, 1601 v_{(\mathrm{C}=\mathrm{C})} \cdot{ }^{1} \mathrm{H}$ NMR $\left(\mathrm{DMSO}_{6}, 400\right.$ $\mathrm{MHz}, \delta, \mathrm{ppm}): 9.24\left(\mathrm{~d}, 1 \mathrm{H}, J_{\mathrm{HH}}=7.2 \mathrm{~Hz}\right), 8.75(\mathrm{~d}, 1 \mathrm{H}$, $\left.J_{\mathrm{HH}}=4.4 \mathrm{~Hz}\right), 8.53\left(\mathrm{~d}, 1 \mathrm{H}, J_{\mathrm{HH}}=8.8 \mathrm{~Hz}\right), 8.37(\mathrm{~d}, 1 \mathrm{H}$, $\left.J_{\mathrm{HH}}=7.6 \mathrm{~Hz}\right), 8.20-8.13(\mathrm{~m}, 2 \mathrm{H}), 7.67\left(\mathrm{t}, 1 \mathrm{H}, J_{\mathrm{HH}}=7.6\right.$ $\mathrm{Hz}), 7.36\left(\mathrm{t}, 1 \mathrm{H}, J_{\mathrm{HH}}=7.6 \mathrm{~Hz}\right)$. UV/Vis $(\mathrm{MeOH}) \lambda_{\max }, \mathrm{nm}$ $\left(\varepsilon, \mathrm{M}^{-1} \mathrm{~cm}^{-1}\right)=222\left(2.12 \times 10^{5}\right), 264\left(1.0 \times 10^{5}\right), 306$ $\left(1.21 \times 10^{5}\right)$. HRMS $($ ESI) $\mathrm{m} / \mathrm{z}$ : calcd.: 196.0749, found:
197.0851 $[\mathrm{M}+\mathrm{H}]^{+}$. Anal. Calcd. $(\%)$ for $\mathrm{C}_{11} \mathrm{H}_{8} \mathrm{~N}_{4} \mathrm{C}$, 67.34; H, 4.11; N, 28.55. Found (\%): C, 67.64; H, 3.91; N, 28.75.

\subsection{Exemplified procedure for the synthesis of complexes 1-4}

A mixture of $\left\{(\text { arene }) \mathrm{MCl}_{2}\right\}_{2}(0.08 \mathrm{mmol})$, ligand $\mathbf{L}(0.16 \mathrm{mmol})$ and $\mathrm{NH}_{4} \mathrm{PF}_{6}(0.16 \mathrm{mmol})$ in methanol $(20 \mathrm{~mL})$ was stirred at room temperature for $6 \mathrm{~h}$ (Scheme 2). Yellow precipitate of the compound was obtained during the course of the reaction. The precipitate was filtered and washed with diethyl ether $(2 \times 15 \mathrm{~mL})$ and air-dried.

2.3a Complex $\left[(p-c y m) R u L \kappa_{N \cap N}^{2} \quad C^{2}\right] P F_{6} \quad(1)$ : Yield: (59\%). FTIR (KBr pellet, $\left.\mathrm{cm}^{-1}\right): 2965 v_{(\mathrm{C}-\mathrm{H})}, 1644 v_{(\mathrm{C}=\mathrm{N})}$, $1611 v_{(\mathrm{C}=\mathrm{C})}, 843 v_{(\mathrm{P}-\mathrm{F}) \text { str }}, 557 v_{(\mathrm{P}-\mathrm{F}) \text { ben }}{ }^{1} \mathrm{H}$ NMR (DMSO$\left.\mathrm{d}_{6}, 400 \mathrm{MHz}, \mathrm{ppm}\right): 9.53\left(\mathrm{~d}, 1 \mathrm{H}, J_{\mathrm{HH}}=6 \mathrm{~Hz}\right), 9.46(\mathrm{~d}, 1 \mathrm{H}$, $\left.J_{\mathrm{HH}}=5.6 \mathrm{~Hz}\right), 8.72\left(\mathrm{~d}, 1 \mathrm{H}, J_{\mathrm{HH}}=4.8 \mathrm{~Hz}\right), 8.52(\mathrm{~d}, 1 \mathrm{H}$, $\left.J_{\mathrm{HH}}=8 \mathrm{~Hz}\right), 8.25\left(\mathrm{t}, 1 \mathrm{H}, J_{\mathrm{HH}}=7.6 \mathrm{~Hz}\right), 7.93\left(\mathrm{t}, 1 \mathrm{H}, J_{\mathrm{HH}}=\right.$ $8.8 \mathrm{~Hz}), 7.64(\mathrm{~m}, 2 \mathrm{H}), 6.20\left(\mathrm{dd}, 2 \mathrm{H}, J_{\mathrm{HH}}=6 \mathrm{~Hz}\right), 5.99$ $\left(\mathrm{t}, 2 \mathrm{H}, J_{\mathrm{HH}}=6.8 \mathrm{~Hz}\right), 2.68(\mathrm{sept}, 1 \mathrm{H}), 2.13(\mathrm{~s}, 3 \mathrm{H})$, $1.03\left(\mathrm{~d}, 6 \mathrm{H}, J_{\mathrm{HH}}=4 \mathrm{~Hz}\right)$. UV-Vis $(\mathrm{MeOH}) \lambda_{\max }, \mathrm{nm}(\varepsilon$, $\left.\mathrm{M}^{-1} \mathrm{~cm}^{-1}\right)=223\left(1.03 \times 10^{5}\right), 294\left(9.5 \times 10^{4}\right), 334$ $\left(6.42 \times 10^{4}\right)$. HRMS (ESI) m/z: calcd.: 467.0576 [M$\left.\mathrm{PF}_{6}\right]^{+}$; found: $467.0604\left[\mathrm{M}-\mathrm{PF}_{6}\right]^{+}$. Anal. Calcd. (\%) for $\mathrm{C}_{21} \mathrm{H}_{22} \mathrm{ClF}_{6} \mathrm{~N}_{4} \mathrm{PRu}$ : C, 41.22; H, 3.62, N, 9.16. Found (\%): C, 41.52; H, 3.32, N, 8.96.

2.3b Complex [\{(benzene)RuL $\left.\kappa_{\mathrm{N} \cap \mathrm{N}}^{2} \mathrm{Cl}_{\}}\right] P \mathrm{~F}_{6}$ (2): Yield: (49\%). FTIR (KBr pellet, $\left.\mathrm{cm}^{-1}\right): 2925 v_{(\mathrm{C}-\mathrm{H})}, 1644 v_{(\mathrm{C}=\mathrm{N})}$, $1612 v_{(\mathrm{C}=\mathrm{C})}, 843 v_{(\mathrm{P}-\mathrm{F}) \text { str }}, 558 v_{(\mathrm{P}-\mathrm{F}) \text { ben }} \cdot{ }^{1} \mathrm{H}$ NMR $\left(\mathrm{DMSO}-\mathrm{d}_{6}\right.$, $400 \mathrm{MHz}, \mathrm{ppm}): 9.65\left(\mathrm{~d}, 1 \mathrm{H}, J_{\mathrm{HH}}=4 \mathrm{~Hz}\right), 9.50(\mathrm{~d}, 1 \mathrm{H}$,

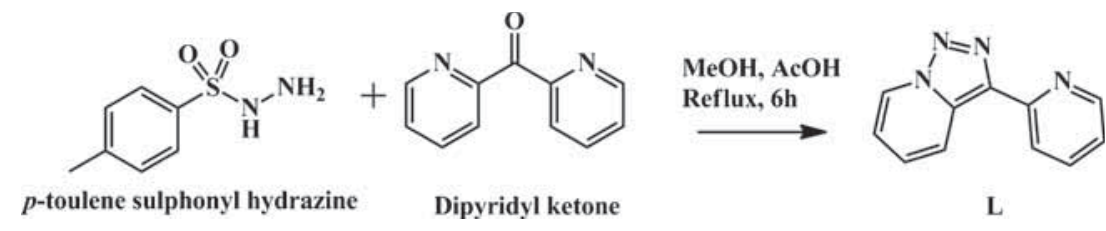

Scheme 1. Schematic representation of the synthesis of ligand.

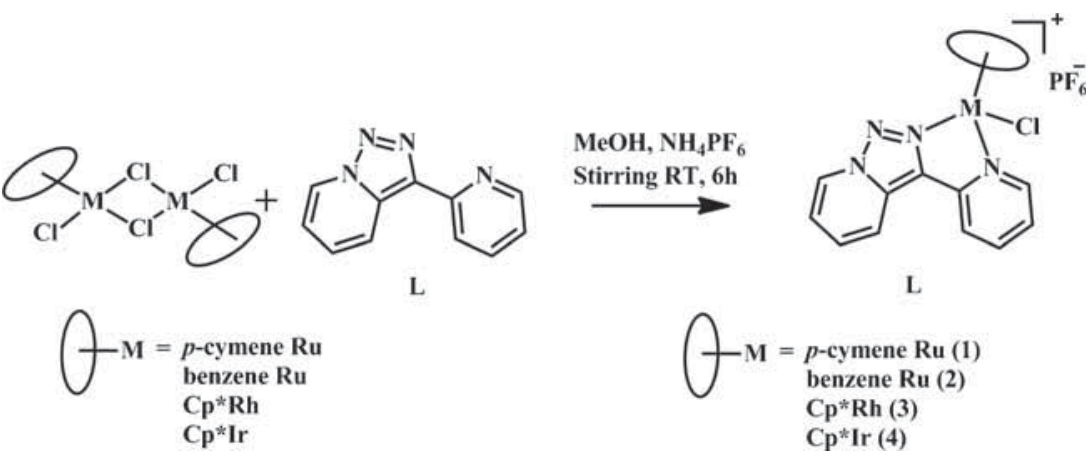

Scheme 2. Schematic representation of the synthesis of complexes 1-4. 
$\left.J_{\mathrm{HH}}=8 \mathrm{~Hz}\right), 8.76\left(\mathrm{~d}, 1 \mathrm{H}, J_{\mathrm{HH}}=8 \mathrm{~Hz}\right), 8.55(\mathrm{~d}, 1 \mathrm{H}$, $\left.J_{\mathrm{HH}}=8 \mathrm{~Hz}\right), 8.29\left(\mathrm{t}, 1 \mathrm{H}, J_{\mathrm{HH}}=8 \mathrm{~Hz}\right), 7.97\left(\mathrm{t}, 1 \mathrm{H}, J_{\mathrm{HH}}=8 \mathrm{~Hz}\right)$, $7.69(\mathrm{~m}, 2 \mathrm{H}), 5.56(\mathrm{~s}, 6 \mathrm{H})$. UV-Vis $(\mathrm{MeOH}) \lambda_{\max }, \mathrm{nm}$ $\left(\varepsilon, \mathrm{M}^{-1} \mathrm{~cm}^{-1}\right)=221\left(9.0 \times 10^{4}\right), 293\left(7.10 \times 10^{4}\right), 332$ $\left(5.23 \times 10^{4}\right)$. HRMS (ESI) m/z: calcd.: 410.9950; found: $410.9964\left[\mathrm{M}-\mathrm{PF}_{6}\right]^{+}$. Anal. Calcd. (\%) for $\mathrm{C}_{17} \mathrm{H}_{14} \mathrm{ClF}_{6} \mathrm{~N}_{4} \mathrm{PRu}$ : C, 36.74; H, 2.54; N, 10.08. Found (\%): C, 36.44; H, 2.84; $\mathrm{N}, 9.95$.

2.3c Complex [Cp $* R h L \kappa_{\mathrm{N} \cap \mathrm{N}}^{2} \mathrm{Cl} \mathrm{PF}_{6}$ (3): Yield: (60\%). FTIR (KBr pellet, $\mathrm{cm}^{-1}$ ): $2945 v_{(\mathrm{C}-\mathrm{H})}, 1640 v_{(\mathrm{C}=\mathrm{N})}, 1609$ $v_{(\mathrm{C}=\mathrm{C})}, 842 v_{(\mathrm{P}-\mathrm{F}) \text { str }}, 558 v_{(\mathrm{P}-\mathrm{F}) \text { ben }} \cdot{ }^{1} \mathrm{H}$ NMR $\left(\mathrm{DMSO}-\mathrm{d}_{6}, 400\right.$ MHz, ppm): $9.51\left(\mathrm{~d}, 1 \mathrm{H}, J_{\mathrm{HH}}=8 \mathrm{~Hz}\right), 9.00\left(\mathrm{~d}, 1 \mathrm{H}, J_{\mathrm{HH}}=\right.$ $8 \mathrm{~Hz}), 8.78\left(\mathrm{~d}, 1 \mathrm{H}, J_{\mathrm{HH}}=8 \mathrm{~Hz}\right), 8.57\left(\mathrm{~d}, 1 \mathrm{H}, J_{\mathrm{HH}}=8 \mathrm{~Hz}\right)$, $8.31\left(\mathrm{t}, 1 \mathrm{H}, J_{\mathrm{HH}}=8 \mathrm{~Hz}\right), 7.96\left(\mathrm{t}, 1 \mathrm{H}, J_{\mathrm{HH}}=8 \mathrm{~Hz}\right), 7.76$ $(\mathrm{m}, 2 \mathrm{H}), 1.78(\mathrm{~s}, 15 \mathrm{H})$. UV-Vis $(\mathrm{MeOH}) \lambda_{\max }, \mathrm{nm}(\varepsilon$, $\left.\mathrm{M}^{-1} \mathrm{~cm}^{-1}\right)=222\left(1.29 \times 10^{5}\right), 266\left(4.51 \times 10^{4}\right), 320(5.1 \times$ $10^{4}$ ). HRMS (ESI) m/z calcd.: 469.0666; found: 469.0804 $\left[\mathrm{M}-\mathrm{PF}_{6}\right]^{+}$. Anal. Calcd. (\%) for $\mathrm{C}_{21} \mathrm{H}_{23} \mathrm{ClF}_{6} \mathrm{~N}_{4} \mathrm{PRhC}$, 41.03; H, 3.77; N, 9.11 Found (\%): 41.33; H, 3.57; N, 9.31.

2.3d Complex $\left[C p^{*} \operatorname{IrL} \kappa_{\mathrm{N} \cap \mathrm{N}}^{2} C l\right] P F_{6}$ (4): Yield: (42\%). FTIR (KBr pellet, $\left.\mathrm{cm}^{-1}\right): 2924 v_{(\mathrm{C}-\mathrm{H})}, 1644 v_{(\mathrm{C}=\mathrm{N})}, 1614$ $v_{(\mathrm{C}=\mathrm{C})}, 844 v_{(\mathrm{P}-\mathrm{F}) \text { str }}, 558 v_{(\mathrm{P}-\mathrm{F}) \text { ben. }}{ }^{1} \mathrm{H}$ NMR $\left(\mathrm{DMSO}-\mathrm{d}_{6}\right.$, $400 \mathrm{MHz}, \delta, \mathrm{ppm}): 9.51\left(\mathrm{~d}, 1 \mathrm{H}, J_{\mathrm{HH}}=8 \mathrm{~Hz}\right), 9.02(\mathrm{~d}$, $\left.1 \mathrm{H}, J_{\mathrm{HH}}=8 \mathrm{~Hz}\right), 8.84\left(\mathrm{~d}, 1 \mathrm{H}, J_{\mathrm{HH}}=8 \mathrm{~Hz}\right), 8.70(\mathrm{~d}, 1 \mathrm{H}$, $\left.J_{\mathrm{HH}}=8 \mathrm{~Hz}\right), 8.33\left(\mathrm{t}, 1 \mathrm{H}, J_{\mathrm{HH}}=8 \mathrm{~Hz}\right), 8.0\left(\mathrm{t}, 1 \mathrm{H}, J_{\mathrm{HH}}=\right.$ $8 \mathrm{~Hz}), 7.71(\mathrm{~m}, 2 \mathrm{H}), 1.77(\mathrm{~s}, 15 \mathrm{H})$. UV-Vis $(\mathrm{MeOH}) \lambda_{\max }, \mathrm{nm}$ $\left(\varepsilon, \mathrm{M}^{-1} \mathrm{~cm}^{-1}\right)=221\left(8.90 \times 10^{4}\right), 287\left(6.89 \times 10^{4}\right), 333$ $\left(5.7 \times 10^{4}\right)$. HRMS $(\mathrm{ESI}) \mathrm{m} / \mathrm{z}$ calcd.: 559.1240; found: $559.1350\left[\mathrm{M}-\mathrm{PF}_{6}\right]^{+}$. Anal. Calcd. (\%) for $\mathrm{C}_{21} \mathrm{H}_{23} \mathrm{ClF}_{6} \mathrm{~N}_{4} \mathrm{PIrC}$, 35.82; H, 3.29; N, 7.96 Found (\%): 36.05; H, 3.49; N, 815.

\section{Results and Discussion}

\subsection{Synthesis}

During an attempt to synthesize a Schiff base ligand by condensing $p$-toulenesulphonyl hydrazine with dipyridyl ketone, we observed the formation of an unexpected triazole ligand (Scheme 1). Though the ligand under study is reported by various methods using oxidizing agents, refluxing in methanol with acetic acid is not widely reported. Complexes 1-4 were obtained by treating ligand $\mathbf{L}$ with the corresponding precursor compound in methanol (Scheme 2). All the complexes were isolated as their hexafluorophosphate salts and were obtained as yellow powders. They are insoluble in chlorinated solvents such as dichloromethane and chloroform, soluble in acetone, alcohols, acetonitrile and dimethyl sulphoxide, soluble in hot water (up to $40^{\circ} \mathrm{C}$ ) and they are insoluble in diethyl ether and hexane.

\subsection{Characterization by spectral studies}

The IR spectra of the mononuclear complexes 1-4 show the stretching frequencies of $\mathrm{C}=\mathrm{N}, \mathrm{C}=\mathrm{C}$ and $\mathrm{C}-\mathrm{H}$ at around 1640, 1610 and $2925 \mathrm{~cm}^{-1}$, respectively. The formation of ionic complexes with $\mathrm{PF}_{6}$ counterion is supported by the presence of P-F vibrational stretching frequency at $842-844 \mathrm{~cm}^{-1}$ and vibrational bending frequencies at $557-558 \mathrm{~cm}^{-1}$.

The ${ }^{1} \mathrm{H}$ NMR spectra of complexes 1-4 exhibit signals corresponding to the ligand from $9.65-7.67 \mathrm{ppm}$

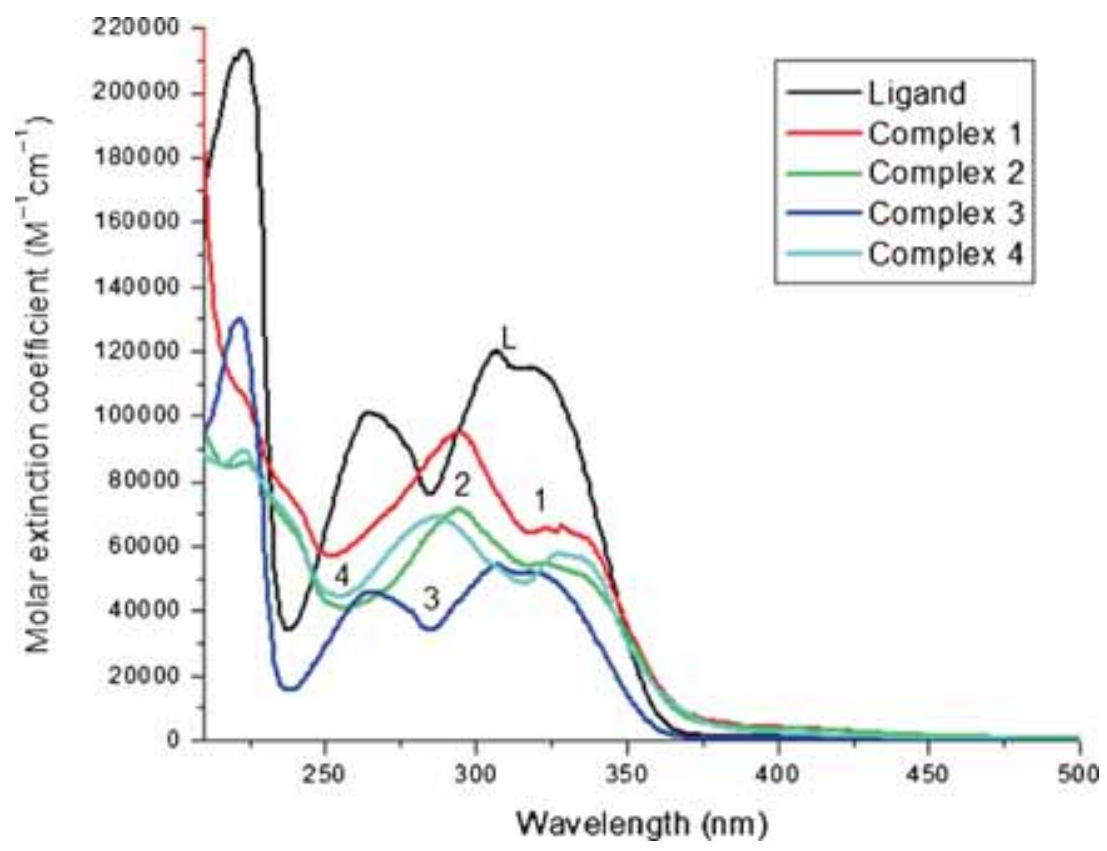

Figure 1. UV-Visible spectra of complexes 1-4 and ligand in methanol at $10 \mu \mathrm{M}$ concentration. 
comprising of doublets, triplets and multiplets corresponding to the two pyridyl rings of the ligand. The ligand in the complexes experiences a downfield chemical shift compared to that of free ligand attributed by the electronegative effect of the metal(s). The presence of the arene metal part is confirmed by the corresponding signals. In complex $\mathbf{1}$, two doublets of doublets at 6.20 and $5.99 \mathrm{ppm}$ corresponding to thephenyl ring of the $p$-cymene, a septet at $2.68 \mathrm{ppm}$, a singlet at $2.13 \mathrm{ppm}$ and a doublet at $1.03 \mathrm{ppm}$ corresponding to the alkyl groups of the $p$-cymene were observed (Figure $\mathrm{S} 1$ in Supplementary Information). The presence of a singlet of six protons at $5.56 \mathrm{ppm}$ in complex 2, a singlet of fifteen protons at $1.78 \mathrm{ppm}$ in complex $\mathbf{3}$ and

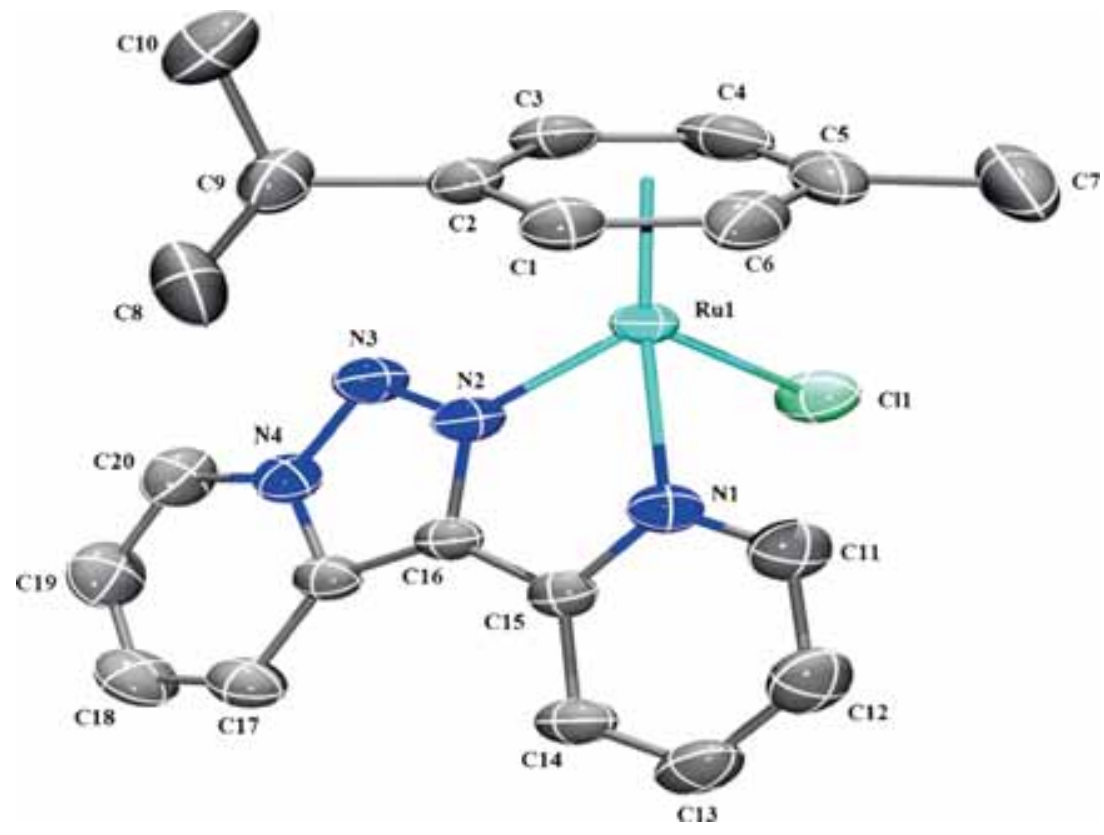

Figure 2. The molecular structure of complex $\mathbf{1}$ as ORTEP diagram at 50\% thermal probability level. Hydrogen atoms and counterions are omitted for clarity.

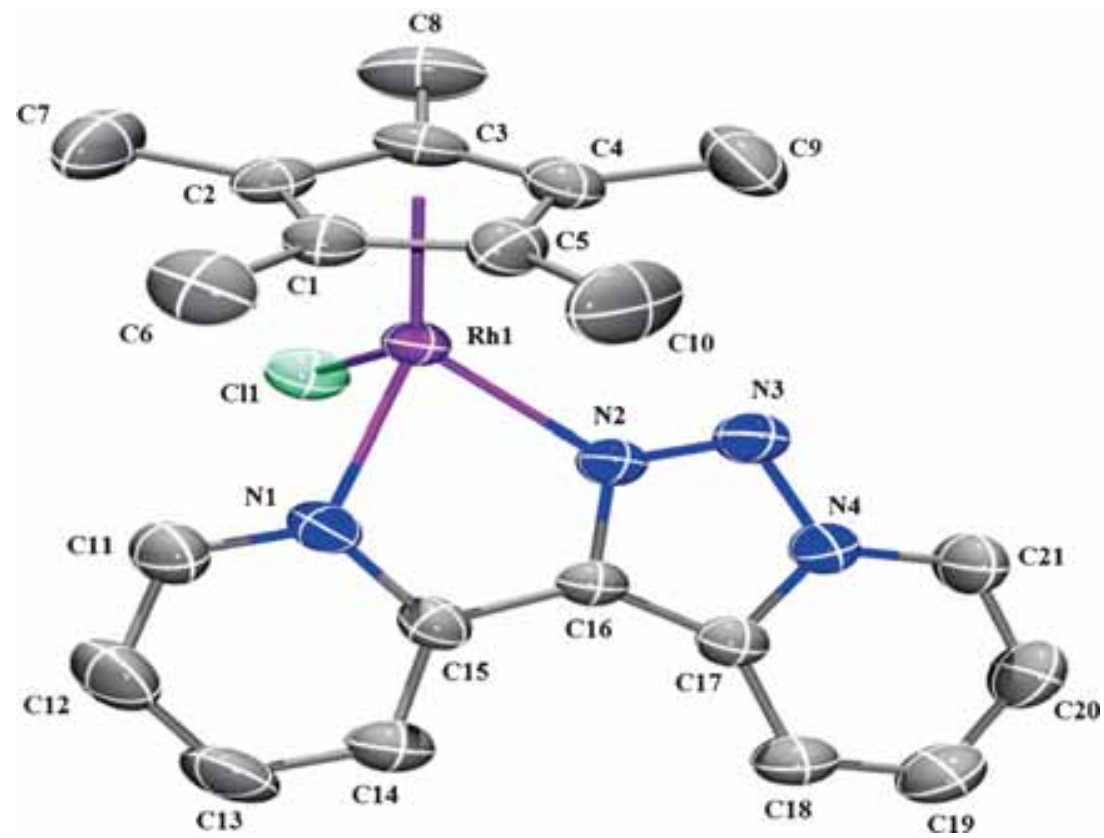

Figure 3. The molecular structure of complex $\mathbf{3}$ as ORTEP diagram at 50\% thermal probability level. Hydrogen atoms and counterions are omitted for clarity. 
Table 1. Crystallographic and structure refinement parameters for complexes $\mathbf{1}$ and $\mathbf{3}$.

\begin{tabular}{|c|c|c|}
\hline & 1 & 3 \\
\hline Empirical formula & $\mathrm{C}_{21} \mathrm{H}_{22} \mathrm{ClF}_{6} \mathrm{~N}_{4} \mathrm{PRu}$ & $\mathrm{C}_{21} \mathrm{H}_{23} \mathrm{ClN}_{4} \mathrm{RhF}_{6} \mathrm{P}$ \\
\hline Formula weight & 611.91 & 614.76 \\
\hline Temperature (K) & $273(2)$ & 293(2) \\
\hline 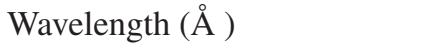 & 0.71073 & 0.71073 \\
\hline Crystal system & Triclinic & Monoclinic' \\
\hline Space group & $P \overline{1}$ & $P 21 / \mathrm{c}$ \\
\hline \multicolumn{3}{|l|}{ Unit cell dimensions $\left(\AA,^{\circ}\right)$} \\
\hline $\mathrm{a}$ & $7.2151(4)$ & $8.1467(16)$ \\
\hline $\mathrm{b}$ & $11.9054(7)$ & $12.368(2)$ \\
\hline $\mathrm{c}$ & $14.8743(8)$ & $24.463(5)$ \\
\hline$\alpha$ & $69.407(5)$ & 90 \\
\hline$\beta$ & $76.898(5)$ & 90 \\
\hline$\gamma$ & $86.939(5)$ & 90 \\
\hline Volume $\left(\AA^{3}\right), \mathrm{Z}$ & 1164.42(12), 2 & $2464.9(8), 4$ \\
\hline Calculated density $\left(\mathrm{mgm}^{-3}\right)$ & 1.745 & 1.657 \\
\hline Absorption coefficient $\left(\mathrm{mm}^{-1}\right)$ & 0.922 & 0.928 \\
\hline Crystal size $\left(\mathrm{mm}^{3}\right)$ & $0.29 \times 0.25 \times 0.12$ & $0.31 \times 0.21 \times 0.21$ \\
\hline Scan range & 3.681 to 26.372 & 3.398 to 26.365 \\
\hline Reflections collected & 7268 & 8922 \\
\hline Independent reflections $\left(\mathrm{R}_{\mathrm{int}}\right)$ & $4868(0.0343)$ & $49930(0.0194)$ \\
\hline Refinement method & Full-matrix least-squares on $\mathrm{F}^{2}$ & Full-matrix least-squares on $\mathrm{F}^{2}$ \\
\hline Data/restraints/parameters & $4866 / 0 / 307$ & $4993 / 0 / 307$ \\
\hline Goodness-of-fit on $\mathrm{F}^{2}$ & 1.045 & 0.749 \\
\hline Final $\mathrm{R}$ indices $[\mathrm{I}>2 \sigma(\mathrm{I})]^{*}$ & $\mathrm{R} 1=0.0410, \mathrm{wR} 2=0.1007$ & $\mathrm{R} 1=0.0555, \mathrm{wR} 2=0.0648$ \\
\hline $\mathrm{R}$ indices (all data) & $\mathrm{R} 1=0.0466, \mathrm{wR} 2=0.1038$ & $\mathrm{R} 1=0.1668, \mathrm{wR} 2=0.1784$ \\
\hline $\begin{array}{l}\text { Largest difference } \\
\text { peak and hole }\left(\mathrm{e} \AA^{-3}\right)\end{array}$ & 0.715 and -0.562 & 1.129 and -1.006 \\
\hline
\end{tabular}

*Structures were refined on $F_{0}^{2}: w R 2=\left[\Sigma\left[w\left(F_{0}^{2}-F_{\mathrm{c}}^{2}\right)^{2}\right] / \Sigma w\left(F_{0}^{2}\right)^{2}\right]^{1 / 2}$, where $w^{-1}=\left[\Sigma\left(F_{0}^{2}\right)+(a P)^{2}+b P\right]$ and $P=$ $\left[\max \left(F_{0}^{2}, 0\right)+2 F_{\mathrm{c}}^{2}\right] / 3$.

Table 2. Selected bond lengths and angles of complexes $\mathbf{1}$ and $\mathbf{3}$.

\begin{tabular}{|c|c|c|}
\hline Complex & 1 & 3 \\
\hline \multicolumn{3}{|l|}{ Bond distances $(\AA)$} \\
\hline $\mathrm{Ru} / \mathrm{Rh}(1)$-Centroid & 1.679 & 1.783 \\
\hline $\mathrm{Ru} / \mathrm{Rh}(1)-$ Arene $_{\mathrm{avg}}$ & 2.1911 & 2.1568 \\
\hline $\mathrm{Ru} / \mathrm{Rh}(1)-\mathrm{N}(1)$ & $2.118(3)$ & $2.164(5)$ \\
\hline $\mathrm{Ru} / \mathrm{Rh}(1)-\mathrm{N}(2)$ & $2.059(3)$ & $2.121(4$ \\
\hline $\mathrm{Ru} / \mathrm{Rh}(1)-\mathrm{Cl}(1)$ & $2.3939(10)$ & $2.3913(15)$ \\
\hline $\mathrm{N}(2)-\mathrm{N}(3)$ & $1.321(4)$ & $1.317(7)$ \\
\hline $\mathrm{N}(3)-\mathrm{N}(4)$ & $1.357(4)$ & $1.374(7)$ \\
\hline $\mathrm{N}(1)-\mathrm{C}(11)$ & $1.347(5)$ & $1.332(7)$ \\
\hline $\mathrm{N}(1)-\mathrm{C}(15)$ & $1.351(4)$ & $1.377(7)$ \\
\hline $\mathrm{N}(2)-\mathrm{C}(16)$ & $1.350(4)$ & $1.359(6)$ \\
\hline $\mathrm{N}(4)-\mathrm{C}(17)$ & $1.374(4)$ & $1.377(7)$ \\
\hline \multicolumn{3}{|l|}{ Bond Angles $\left({ }^{\circ}\right)$} \\
\hline $\mathrm{N}(1)-\mathrm{Ru} / \mathrm{Rh}(1)-\mathrm{N}(2)$ & $76.21(11)$ & $76.11(15)$ \\
\hline $\mathrm{N}(1)-\mathrm{Ru} / \mathrm{Rh}(1)-\mathrm{Cl}(1)$ & $84.53(8)$ & $87.78(12)$ \\
\hline $\mathrm{N}(2)-\mathrm{Ru} / \mathrm{Rh}(1)-\mathrm{Cl}(1)$ & $85.15(8)$ & $89.88(12)$ \\
\hline $\mathrm{N}(2)-\mathrm{N}(3)-\mathrm{N}(4)$ & $103.5(3)$ & $104.6(4)$ \\
\hline $\mathrm{N}(3)-\mathrm{N}(2)-\mathrm{C}(16)$ & $112.8(3)$ & $112.1(4)$ \\
\hline $\mathrm{N}(1)-\mathrm{C}(15)-\mathrm{C}(16)-\mathrm{N}(2)$ & 5.49 & 0.45 \\
\hline
\end{tabular}


Table 3. Selected hydrogen bond distances $(\AA)$ and angles $\left(^{\circ}\right)$ of complexes $\mathbf{1}$ and $\mathbf{3}$.

\begin{tabular}{lccccc}
\hline Complex & $\mathrm{D}-\mathrm{H} \cdots \mathrm{A}$ & $\mathrm{D}-\mathrm{H}(\AA)$ & $\mathrm{H} \cdot \cdots \mathrm{A}(\AA)$ & $\mathrm{D} \cdots \mathrm{A}(\AA)$ & $<\mathrm{D}-\mathrm{H} \cdot \mathrm{A}\left({ }^{\circ}\right)$ \\
\hline 1 & $\mathrm{C}(1)-\mathrm{H}(1) \cdots \mathrm{Cl}(1)^{\mathrm{a}}$ & 0.980 & 2.680 & $3.642(4)$ & 168 \\
& $\mathrm{C}(18)-\mathrm{H}(18) \cdots \mathrm{Cl}(1)^{\mathrm{b}}$ & 0.930 & 2.670 & $3.477(4)$ & 145 \\
3 & $\mathrm{C}(15)-\mathrm{H}(15) \cdots \mathrm{Cl}(1)^{\mathrm{c}}$ & 0.930 & 2.810 & $3.776(6)$ & 154 \\
\hline
\end{tabular}

$*$ Symmetry axis: $\mathrm{a}=-1+\mathrm{x}, \mathrm{y}, \mathrm{z} . \mathrm{b}=2-\mathrm{x}, 1-\mathrm{y},-\mathrm{z}, \mathrm{c}=1-\mathrm{x},-\mathrm{y},-\mathrm{z}$.

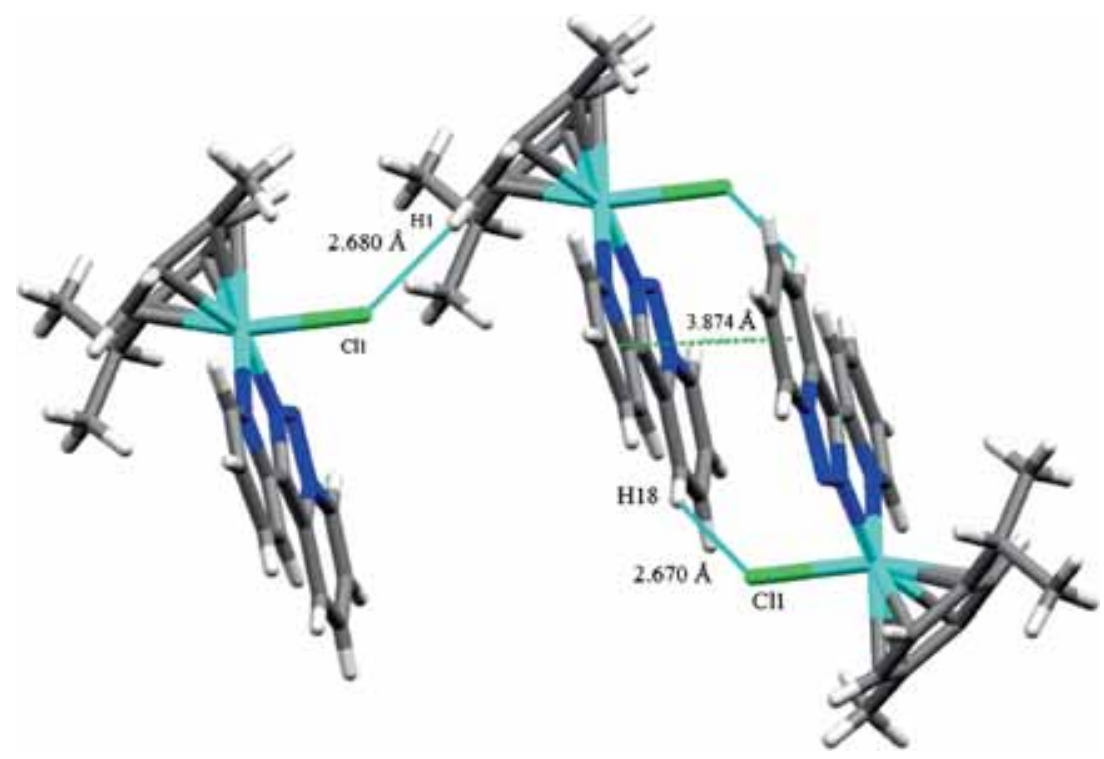

Figure 4. Intermolecular $\mathrm{C}-\mathrm{H} \cdots \mathrm{Cl}$ interactions in complex $\mathbf{1}$.

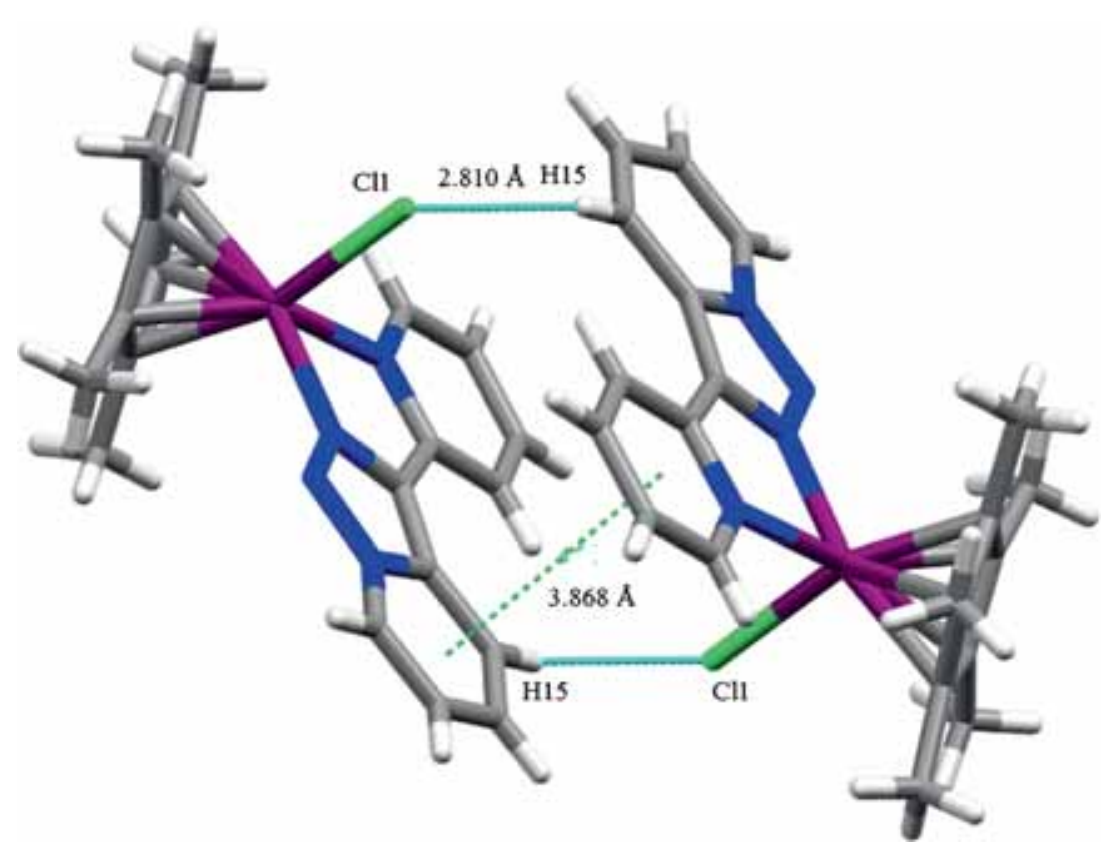

Figure 5. Intermolecular $\mathrm{C}-\mathrm{H} \cdots \mathrm{Cl}$ interactions in complex 3 . 
that at $1.77 \mathrm{ppm}$ in complex 4 confirm the presence of benzene ruthenium, $\mathrm{Cp} * \mathrm{Rh}$ and $\mathrm{Cp} * \mathrm{Ir}$ portions of the complexes (Figures S2-S4 in Supplementary Information). Mass spectral study by HRMS has unambiguously confirmed the formation of the complexes. The molecular ion peaks in complexes $\mathbf{1} \mathbf{- 4}$ corresponding to the $\left[\mathrm{M}-\mathrm{PF}_{6}\right]^{+}$were found at $\mathrm{m} / \mathrm{z} 467.0604,410.9964$, 469.0804 and 559.1350 respectively (Figures S6-S9 in Supplementary Information). UV-Vis spectra of the ligand and complexes 1-4 were recorded in methanol in $10 \mu \mathrm{M}$ solutions. The electronic spectra of these complexes are depicted in (Figure 1). The ligand exhibited three bands at 222, 264 and $306 \mathrm{~nm}$. The electronic spectra of complexes 1-4 display three bands at 221$223 \mathrm{~nm}, 287-294 \mathrm{~nm}$ and $320-334 \mathrm{~nm}$. There is a significant bathochromic shift in the lower energy bands from $264 \mathrm{~nm}$ to $\sim 290 \mathrm{~nm}$ and from 306 to $\sim 330 \mathrm{~nm}$.

\subsection{Structural studies by X-ray crystallography}

The molecular structures of complexes $\mathbf{1}$ and $\mathbf{3}$ were confirmed by X-ray structural analyses. The ORTEP drawings with an atom labelling scheme are shown in Figures 2 and 3. The summary of the crystallographic data, bond lengths and angles for these complexes are presented in Tables 1 and 2, respectively. The chelate binding of the ligand and the formation of cationic complexes are explicit in the crystal structures. The metal to centroid distances in complexes $\mathbf{1}$ and $\mathbf{3}$ are $1.679 \AA$ and $1.783 \AA$, respectively, which indicates a longer distance of the arene and metal in the latter case.

In complexes $\mathbf{1}$ and $\mathbf{3}$, metal to nitrogen distances around the metal viz., Ru/Rh-N1/N2 are in the range $2.059 \AA$ to $2.164 \AA$ and the metal chloride distances are $2.393 \AA$ and $2.391 \AA$, respectively. In the triazole, the N-N distances viz., N2-N3 and N3-N4 in complex 1 are 1.321(4) $\AA$ and 1.357(4) $\AA$, respectively, and in complex 3 they are 1.317(7) $\AA$ and 1.374(7) $\AA$, respectively, which suggest that the N-N bond attached to pyridine ring is longer than the exocyclic N-N bond which is bound to the metal (Figures 2 and 3). The bite angles around the metal $\mathrm{N}(1)-\mathrm{Ru} / \mathrm{Rh}(1)-\mathrm{N}(2)$, $\mathrm{N}(1)-\mathrm{Ru} / \mathrm{Rh}(1)-\mathrm{Cl}(1)$ and $\mathrm{N}(2)-\mathrm{Ru} / \mathrm{Rh}(1)-\mathrm{Cl}(1)$ are in therange $76.11(15)^{\circ}$ to $89.88(12)^{\circ}$ which shows a slight deviation from the octahedral geometry resulting in pseudo-octahedral geometry for the complexes. The complexes resemble a "piano stool" with arene occupying the place of the seat and the two nitrogen atoms and chloride as the three legs. The torsion angle at $\mathrm{N}(1)-\mathrm{C}(15)-\mathrm{C}(16)-\mathrm{N}(2)$ in complexes $\mathbf{1}$ and $\mathbf{3}$ are 5.49 and $0.45^{\circ}$ which suggests the existence of more strain around the metal in the ruthenium complex compared to that of rhodium. The packing diagrams of the crystal structures of the complexes $\mathbf{1}$ and $\mathbf{3}$ show the intermolecular $\mathrm{C}-\mathrm{H} \cdots \mathrm{Cl}$ interaction and $\pi-\pi$ interaction. In complex 1, C1-H1 ‥ Cl was observed with $2.680 \AA$ between the donor and acceptor and C(18)$\mathrm{H}(18) \cdots \mathrm{Cl}(1)$ was observed with $2.670 \AA$ between the donor and acceptor. In complex $\mathbf{3}, \mathrm{C}(15)-\mathrm{H}(15) \cdots \mathrm{Cl}(1)$ was observed with $2.810 \AA$ between the donor and acceptor (Figures 4 and 5) (Table 3).

\section{Conclusions}

In our attempt to synthesize a Schiff base ligand by condensing tosylhydrazine with dipyridyl ketone using glacial acetic acid, we ended up with triazolylpyridine by nucleophilic substitution of the tosyl group by pyridyl nitrogen (ligand $\mathbf{L}$ ). All the three metal precursors $(\mathrm{M}=\mathrm{Ru}, \mathrm{Rh}$ and $\mathrm{Ir})$ form mononuclear cationic complexes with the ligand in $N, N$-bidentate chelating mode $\left(\kappa^{2} N \cap N\right)$. The metal complexes 1-4 were synthesized and characterized by spectroscopic and crystallographic studies. Complexes under study exhibited a significant bathochromic shift from ligand to complexes in the lower energy region from $264 \mathrm{~nm}$ to $\sim 290 \mathrm{~nm}$ and from 306 to $\sim 330 \mathrm{~nm}$. Complexes 1 and $\mathbf{3}$ exhibited intermolecular $\mathrm{C}-\mathrm{H} \cdots \mathrm{Cl}$ and $\pi-\pi$ interactions.

\section{Supplementary Information (SI)}

CCDC [1505760] and CCDC [1505761] contain the supplementary crystallographic data for complexes $\mathbf{1}$ and $\mathbf{3}$. These data can be obtained free of charge via www.ccdc.cam.ac. uk/data_request/cif,by e-mailing data_request@ccdc.cam.ac.uk, or by contacting The Cambridge Crystallographic Data Centre, 12, Union Road, Cambridge CB2 1EZ, UK; fax: +44 1223 336033. ${ }^{1} \mathrm{H}$ NMR and mass spectra of the corresponding complexes are given in the Supplementary Information, which is available at www.ias.ac.in/chemsci.

\section{Acknowledgements}

P N Rao thanks, UGC, New Delhi for providing fellowship in the form of SRF. Authors thank DST-PURSE SCXRD, Department of Chemistry, NEHU for X-ray analysis data. Authors thank Mr. B. Adinarayana (NISER-B) and M. Srinivasa Rao (IITG) for their support in NMR and mass analyses.

\section{References}

1. Kleverlaan C J, Indelli M T, Bignozzi C A, Pavanin L, Scandola F, Hasselman G M and Meyer G J 2000 Stepwise Charge Separation in Heterotriads. Binuclear $\mathrm{Ru}(\mathrm{II})-\mathrm{Rh}$ (III) Complexes on Nanocrystalline Titanium Dioxide J. Am. Chem. Soc. 1222840 
2. Lees A C, Evrard B, Keyes T E, Vos J G, Kleverlaan C J, Alebbi M and Bignozzi C A 1999 Synthesis, Spectroscopy and Photophysical Properties of Ruthenium Triazole Complexes and Their Application as Dye-Molecules in Regenerative Solar Cells Eur. J. Inorg. Chem. 122309

3. Noyori R and Hashigushi S 1997 Asymmetric Transfer Hydrogenation Catalyzed by Chiral Ruthenium Complexes Acc. Chem. Res. 3097

4. Mayer T J and Huynh M H V 2003 The Remarkable Reactivity of High Oxidation State Ruthenium and Osmium Polypyridyl Complexes Inorg. Chem. 428140

5. Nakajima H and Nagao Hand Tanaka K 1996 Control of the coordination mode of 1,8-napthyridine ligated to ruthenium(II) bipyridine complexes Dalton Trans. 1405

6. Habtemariam M, Melchart R, Fernandez S, Parsons I D H, Oswald A, Parkin F P A, Fabbiani J E, Davidson A, Dawson R E, Aird D I, Jodrell and Sadler P J 2006 Structure-Activity Relationships for Cytotoxic Ruthenium(II) Arene Complexes Containing N,N-, N,O-, and O,O-Chelating Ligands J. Med. Chem. 496858

7. Melchart M, Habtemariam A, Novakova O, Moggach S A, Fabbiani F P A, Parsons S, Brabec V and Sadler P J 2007 Bifunctional amine-tethered ruthenium(II) arene complexes form monofunctional adducts on DNA Inorg. Chem. 468950

8. Pandia A K, Ashoka K and Samuelson G 2015 Synthesis and unexpected reactivity of $\left[\mathrm{Ru}\left(\eta^{6}\right.\right.$-cymene) $\left.\mathrm{Cl}_{2}\left(\mathrm{PPh}_{2} \mathrm{Cl}\right)\right]$, leading to $\left[\mathrm{Ru}\left(\eta^{6}\right.\right.$-cymene $\left.) \mathrm{Cl}_{2}\left(\mathrm{PPh}_{2} \mathrm{OH}\right)\right]$, complexes J. Chem. Sci. 1271329

9. Rakesh K, Rath G and Nagana G 2002 Half-sandwich $\left(\eta^{6}\right.$-arene) ruthenium(II) chiral Schiff base complexes: Analysis of the diastereomeric mixtures in solution by 2D-NMR spectroscopy J. Chem. Sci. 114461

10. Hirayama T, Ueda S, Okada T, Tsurue N, Okuda K and Nagasawa H 2014 Facile One-Pot Synthesis of $[1,2,3]$ Triazolo[1,5-a]Pyridines from 2-Acylpyridines by Copper(II)-Catalyzed Oxidative N-N Bond Formation Chem. Eur. J. 204156

11. Niel V, Gaspar A B, MuÇoz M C, Abarca B, Ballesteros $\mathrm{R}$ and Real J A 2003 Spin crossover behaviour in the iron(II)-2-pyridyl[1,2,3]triazolo[1,5-a]pyridine system: X-ray structure, calorimetric, magnetic, and photomagnetic studies Inorg. Chem. 424782

12. Maury G, Meziane D, Sraïr D, Paugan J P and Paugam R 1982 1,2,3-Triazolo(1,5)Azines et Autres Hétérocycles Azotés Dérivés D’Azine-carboxaldéhydes Bull. Soc. Chim. Belg. 91153

13. Battaglia L P, Carcelli M, Ferraro F, Mavilla L, Pelizzi C and Pelizzi G A 1994 Convenient method for the preparation of 3-(2-pyridyl)triazolo[1,5-a]pyridine (L) Crystal structures of $\mathrm{L}$ and $\left[\mathrm{CuL}_{2}\left(\mathrm{OH}_{2}\right)_{2}\right]\left[\mathrm{NO}_{3}\right]_{2}$ Dalton Trans. 2651

14. Abarca B, Alkorta I, Ballesteros R, Blanco F, Chadlaoui M, Elguero J and Mojarrad F 2005 An experimental and theoretical (DFT) study of the ring chain isomerization Org. Biomol. Chem. 33905

15. Klingele J, Kaase D, Hilgert J, Steinfeld G, Klingele M H and Lach J 2010 Triazolopyridines as ligands: Structural diversity in iron(II), cobalt(II), nickel(II) and copper(II) complexes of 3-(2-pyridyl)$[1,2,4]$ triazolo[4,3-a]- pyridine and spin crossover in $\left[\mathrm{Fe}(\mathrm{II})(\mathrm{L})_{2}(\mathrm{NCS})_{2}\right]$ Dalton Trans. 4495
16. Abarca B, Ballesteros R and Chadlaoui M 2004 Triazolopyridines. Part 24: New polynitrogenated potential helicating ligands Tetrahedron $\mathbf{6 0} 5785$

17. Abarca-Gonzalez B J 2002 The Chemistry of [1,2,3]Triazolo[1,5-a] pyridines Enzyme Inhib. Med. Chem. 17359

18. Niel V, Gaspar A B, Munoz M C, Abarca B, Ballesteros $\mathrm{R}$ and Real J A 2003 Spin Crossover Behavior in the Iron(II)-2-pyridyl[1,2,3]triazolo[1,5-a]pyridine System: X-ray Structure, Calorimetric, Magnetic, and Photomagnetic Studies Inorg. Chem. 424782

19. Amadei E, Carcelli M, Ianelli S, Cozzini P, Pelagatti P and Pelizzi C 1998 Ligand behaviour and reactivity of phenyl 2-pyridyl ketone azine. Structures of two polymorphic forms of the azine and a copper complex of the 3-phenyltriazolo[1,5-a]pyridine Dalton Trans. 1025

20. Ballesteros R, Abarca B, Samadi A, Server-Carrio $\mathrm{J}$ and Escriva E 1999 Coordinating behaviour of 3-methyl[1,2,3]triazolo[1,5-a]pyridine (tzpy): Crystal and molecular structure and electronic properties of $\left[\mathrm{Cu}(\mathrm{tzpy})_{2}\left(\mathrm{ONO}_{2}\right)_{2}\left(\mathrm{OH}_{2}\right)\right]$ Polyhedron 183129

21. Richardson C and Steel P J 2002 Metal Complexes of 2-[1,2,3-thia(and selena)diazol-4-yl]pyridine and an Unusual Silver-induced Selenadiazole Rearrangement Aust. J. Chem. $\mathbf{5 5} 783$

22. Fitchett C M, Keene F R, Richardson C and Steel P J 2008 Triazolopyridines. Part 24: New polynitrogenated potential helicating ligands Inorg. Chem. Commun. 11595

23. Rao A V, Prasad K T, Wang P and Rao K M 2012 Study of half-sandwich mono and dinuclear complexes of platinum group metals containing pyrazolyl pyridine analogues: Synthesis and spectral characterization J. Chem. Sci. 124565

24. Mahesh K, Forbes S, Mozharivskyj Y and Rao K M 2015 Half-sandwich $\eta^{6}$-arene ruthenium and $\mathrm{Cp} *$ rhodium/ iridium compounds comprising with thioether ligands: Synthesis, spectral and molecular studies J. Chem. Sci. 1271135

25. Armarego W L and Chai C L L 2013 In Purification of laboratory chemicals (Butterworth-Heinemann: London)

26. Bennett $\mathrm{M}$ A, Huang $\mathrm{T} \mathrm{N}$, Matheson $\mathrm{T}$, Smith A, Ittel S and Nickerson W 2007 ( $\eta^{6}$-Hexamethylbenzene)Ruthenium Complexes Inorg. Synth. 2174

27. White C, Yates A, Maitlis $P$ and Heinekey D $2007\left(\eta^{5}\right.$-Pentamethylcyclopentadienyl)Rhodium and -Iridium compounds Inorg. Synth. 29228

28. Crysalis PRO, release 2012 Version 1.171.36.20. Agilent Technologies, Yarnton

29. Sheldrick G M 2008 Acta. Crystallogr. A 64112

30. Sheldrick G M 2015 Acta. Crystallogr. C 713

31. Farrugia L J 1997 ORTEP-3 for Windows -a version of ORTEP-III with a Graphical User Interface (GUI) $J$. Appl. Crystallogr. 30565

32. Bruno I, Cole J, Edgington P, Kessler M, Macrae C F, Cabe P M, Pearson J and Taylor R 2002 New software for searching the Cambridge structural database and visualising crystal structures Acta Crystallogr. B 58389 